\title{
Role of Undenatured collagen type II and Aflapin combination in the management of osteoarthritis: a review
}

\author{
Karun Jain', Apurv A. Mehra ${ }^{2}$, Kapil D. Mehta ${ }^{3}$, Lyndon Dsouza ${ }^{3 *}$, Ratna Kumar ${ }^{3}$
}

\begin{abstract}
${ }^{1}$ Department of Orthopedics, Pushpanjali Medical Centre, Delhi, India
${ }^{2}$ Department of Orthopedics, Max Institute of Bone and joint care, Delhi, India

${ }^{3}$ Medical Affairs Department, Wockhardt Ltd. Mumbai, Maharashtra, India
\end{abstract}

Received: 26 May 2021

Revised: 17 June 2021

Accepted: 18 June 2021

\section{*Correspondence: \\ Lyndon Dsouza, \\ Email: LDsouza@wockhardt.com}

Copyright: ( ) the author(s), publisher and licensee Medip Academy. This is an open-access article distributed under the terms of the Creative Commons Attribution Non-Commercial License, which permits unrestricted non-commercial use, distribution, and reproduction in any medium, provided the original work is properly cited.

\begin{abstract}
Osteoarthritis (OA) is the most common joint disease affecting millions worldwide. Osteoarthritis typically affects the knees, hands, hips, and feet. It is characterized by complex pathologic changes in the cartilage which haven't been fully elucidated yet. However, recent research has shown the involvement of two contributing pathways namely the mechanical and the immune pathways which interlink to cause cartilage destruction. Patients with OA on current treatment options still inevitably progress to a more severe stage becoming candidates for total joint replacement. The cornerstones of OA management in the early stage include exercises, weight loss, education — complemented by topical or oral nonsteroidal anti-inflammatory drugs (NSAIDs) and nutraceuticals like Undenatured type II collagen and Aflapin. Both Undenatured type II collagen and Aflapin offer great promise in OA management by targeting both the immune and mechanical pathways respectively. Undenatured type II collagen works by oral tolerization turning off the immune response in the inflammatory damage ( $\mathrm{T}$ cell response) against endogenous Type II collagen in the cartilage thus reducing joint inflammation, degradation and stimulates anti-inflammatory cytokine release. Aflapin inhibits 5LOX and exerts anti-inflammatory action thus providing symptomatic relief of pain and inflammation. This review focusses on the role of mechanical and immune pathways in the pathogenesis of OA and the impact of the combination of Undenatured type-II collagen and Aflapin in targeting these pathways thus improving the clinical outcomes.
\end{abstract}

Keywords: Aflapin, Undenatured type-II collagen, Pathogenesis, Mechanical pathway, Immune pathway, Osteoarthritis

\section{INTRODUCTION}

Osteoarthritis is the most common degenerative joint disease in adults and a major cause of pain and disability. It is frequently compounded by the presence of multimorbidities such as ageing and obesity. Osteoarthritis (OA) affects more than $25 \%$ of the population over 18 years old. Because aging is an influential risk factor for $\mathrm{OA}$, a majority of people over the age of 65 were diagnosed with radiographic changes in one or more joints. A hallmark of aging chondrocytes is the reduced capacity to repair. ${ }^{1}$ This disabling condition is a substantial health burden with 250 million worldwide currently affected. ${ }^{2}$

Pain is a customary symptom occurring at various points in the day like in the early morning hours, early evening and night interfering with sleep as observed in severe OA. This may reduce the quality of life in the patient.

OA can be categorized into localized or generalized forms involving single or multiple joints. The knee, which may also be associated with falls, is an important target site for 
$\mathrm{OA}$ and is the commonest single cause of lower-limb disability in adults over age 50 worldwide. Hand and Hip $\mathrm{OA}$ are the less common types of OA. Hip OA can rapidly progress from onset of pain to join destruction and instability in just a few months. . $^{3,4}$

Amongst the myriad options available for treatment of $\mathrm{OA}$, there is still an unmet clinical need. The dearth of treatment options preventing clinical progression present a grave situation in OA management. Current treatment options include exercise, heat/cold therapy, joint protection, weight loss, physiotherapy/occupational therapy and medications. The most common medications used for pain relief include Non-steroidal antiinflammatory drugs (NSAIDs). Although these drugs are effective for reducing pain, they do not reverse the disease and show considerable side effects. As a result, physicians have turned to nutraceuticals to ease the patient's pain and discomfort. They are well tolerated and considered safe.

Based on recent tenable evidence in the pathogenesis of OA, two important pathways presumably play a crucial role in OA progression. For the sake of this review we would be focussing on drugs like Aflapin and Undenatured collagen type II as suitable options for treatment of OA which act on the two major pathways namely the mechanical and immune pathways thus preventing progression of OA.

\section{PATHOGENESIS OF OA}

Osteoarthritis (OA) has been generally considered to be a degenerative joint disease caused by biomechanical alterations and aging. However, recent research points out the involvement of specific pathways in the pathogenesis of OA. Current studies have revealed the role of both the mechanical and immune pathways in the pathogenesis of OA. The mechanical pathway is predominantly inflammatory, evidenced by symptoms while the immune pathway displays the immune reactivity to cartilage antigens. $^{5}$

\section{MECHANICAL PATHWAY}

The mechanical pathway is triggered by mechanical injuries like trauma, mechanical stress, joint overuse, tissue damage etc. This subsequently initiates the production of inflammatory cytokines, chemokines, and destructive enzymes. The resulting degradation of the cartilage matrix may subsequently lead to an autoimmune reaction to the cartilage. 5- lipoxygenase (5-LOX) enzyme is postulated to play an important role in the OA pathogenesis by releasing various inflammatory cytokines and enzymes such as matrix metalloproteinases (MMPs) triggering articular cartilage breakdown. ${ }^{6,7}$ This may lead to an imbalance between the anabolic and catabolic pathways. Catabolic proinflammatory cytokines, such as Interleukin- $1 \beta$ and tumor necrosis factor $\alpha$ (TNF $\alpha$ ), play major roles in the deterioration of extracellular matrix (ECM) especially in early OA. ${ }^{8}$ Particularly, IL-1 $\beta$ and
TNF $\alpha$ are up-regulated in OA. ${ }^{9}$ They play several roles in driving the inflammatory cascade in chondrocytes either independently or in collaboration with other cytokines (Figure 1). Firstly, they trigger the production of the MMP family involved in matrix degradation by cleaving the peptide bond of target proteins. They also destroy articular cartilage by suppressing the synthesis of type II collagen and proteoglycans in chondrocytes. IL-1 $\beta$ causes cell proliferation, differentiation, and apoptosis. It also induces production of reactive oxygen species (ROS), TNF- $\alpha$ in the chondrocytes along with IL-17 and IL-22 and proinflammatory cytokines like IL-6, IL-8 which are elevated in OA. ${ }^{10}$ Other cytokines, like IL-18, are potent inducers of catabolic responses in chondrocytes. ${ }^{11}$ Chemokines, novel, small cytokines also recruit $\mathrm{T}$ helper cells (Th1, Th17) and (Th22). There is ample evidence for inappropriate activation of the chemokine network in OA especially in the synovial fluid. ${ }^{12,13}$ Investigators have noted the expression of CCR1, CCR2, CCR3, CCR5 and CXCR1 in OA chondrocytes. ${ }^{14,15}$ While the proinflammatory cytokines and chemokines represent the "marching orders", proteolytic enzymes of the MMP family are the actual mediators on "the frontline" causing actual degradation of the articular cartilage.

\section{IMMUNE PATHWAY}

The pathologic process of OA also might involve cellular immunity. Endogenous articular cartilage components provide a rich source of antigenic peptides in osteoarthritis. Humoral and cellular immune responses to cartilage proteoglycans have been reported. The exposure of cartilage components to the immune system may initiate the production of inflammatory cytokines and destructive enzymes which degrade and destroy the cartilage matrix. This leads to an autoimmune reaction to the cartilage in $\mathrm{OA}$, causing further destruction of the cartilage, which in turn could lead to a chronic inflammation. Evidence also indicates that chondrocytes bear unique surface antigens. ${ }^{15}$ Cartilage collagens induce inflammatory arthritis which has uniformly been accepted as an immune-mediated arthropathy. ${ }^{16}$ The immune pathway progression takes place when chondrocytes come in direct contact with $\mathrm{T}$ cells. ${ }^{17}$ In investigations, the number of interferon- $\gamma$ (IFN $\gamma$ )-positive cells (Th1) was found to be $\sim 5$ times higher than the number of interleukin-4 (IL-4)-positive cells (Th2) in the synovium of OA patients. ${ }^{18}$ This shows a Th1 cell-mediated specific immune response is driven by local antigens. This leads to initiation of synthesis of pro-inflammatory cytokines as well as destructive enzymes resulting into the further destruction of cartilage matrix. T cells also damage the cellular integrity and increase inflammation by producing autoantibodies against cartilage cell surface proteins like collagen. ${ }^{19}$ Other investigations have also identified the involvement of humoral immunity in OA, including the presence of autoantibodies against cartilage components. ${ }^{20}$ One study showed that the immune complex deposits in OA cartilage contained significantly high titres of anti-type II collagen antibodies (Figure 1). ${ }^{21}$ 


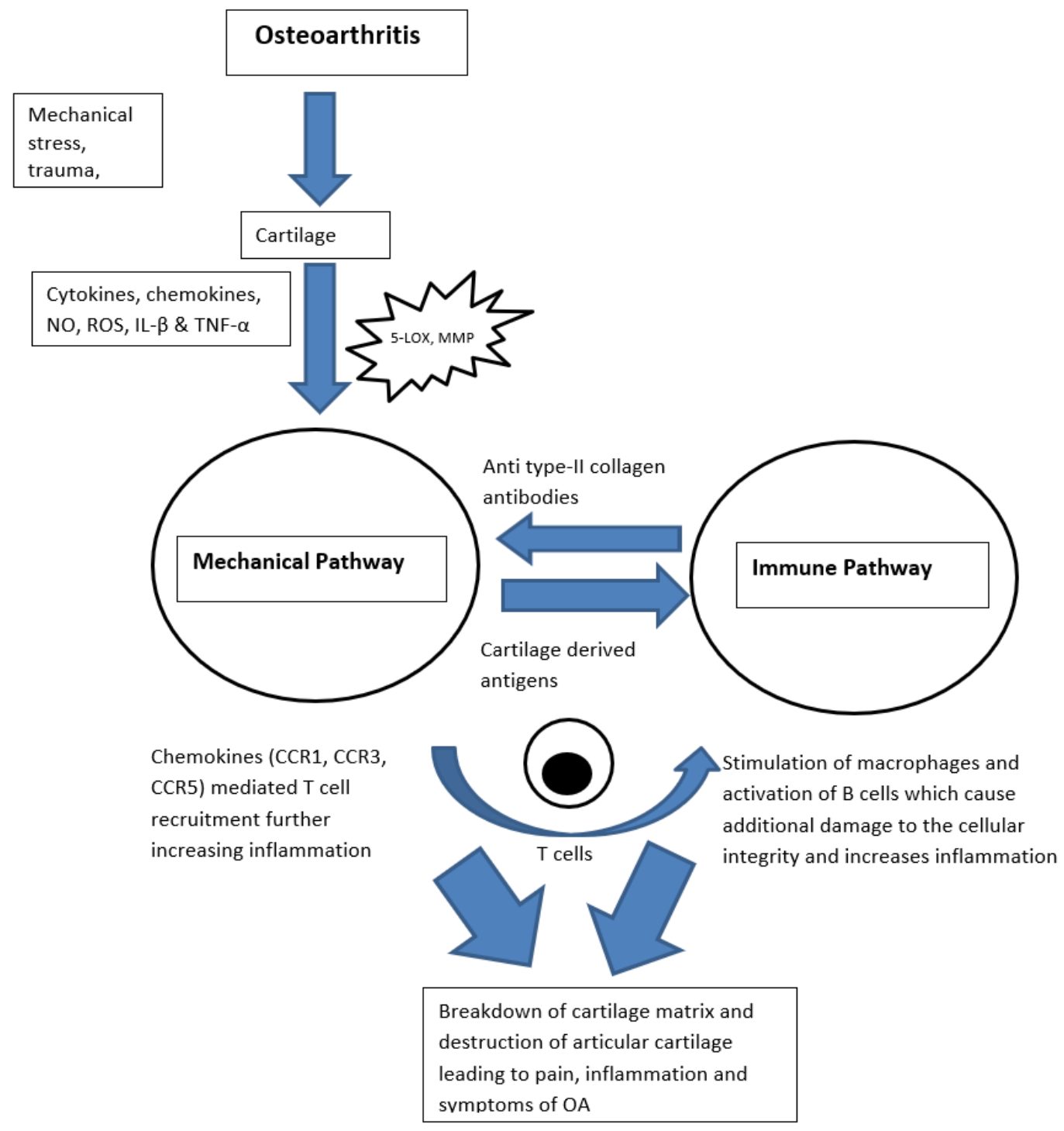

Figure 1: Pathogenesis of OA: role of mechanical and immune pathways.

NO-Nitrous oxide, ROS- Reactive oxygen species, IL- $\beta$ - Cytokine Interleukin - $1 \beta$, TNF- $\alpha$ - Tumor Necrosis Factor $\alpha, 5$ - LOXArachidonate 5-lipoxygenase, MMP- Matrix metalloproteinases, T \& B cells- types of lymphocytes.

The combined interplay of both the mechanical and the immune pathways lead to cartilage destruction and inflammation in OA.

\section{MANAGEMENT}

The aim of osteoarthritis management is to alleviate pain, improve joint function, quality of life and alter the joint damage mechanism. For this, a customized multipronged approach according to individual needs should be in place. Existing treatment approaches include non-pharmacological, pharmacological and surgical. Non-pharmacological methods like exercises, self-management programs, weight loss, tai chi, cane, and tibio femoral knee brace are the main stays of treatment. ${ }^{22}$ Pharmacological management should be tried in symptomatic patients when initial non pharmacological therapies fail. Several medications like Non-steroidal anti-inflammatory drugs (NSAIDs) and analgesics are used for short term pain relief in OA patients. However, recent safety concerns necessitate use with caution. ${ }^{23}$ NSAIDs are used to treat initial inflammation which drives disease progression. ${ }^{24}$ NSAIDS are superior to Acetaminophen in controlling symptomatic pain, but are associated with increased gastrointestinal, cardiac and renal side effects. ${ }^{25,26}$ Topical NSAIDS minimize side effects with similar therapeutic effect compared to their oral counterparts. They act locally with least systemic exposure and should be preferred before starting oral NSAIDS; however, dermatological side effects and tissue absorption limit their use. ${ }^{27}$ Rubefacients like topical capsaicin are seen to reduce pain by counter irritant mechanism and enhanced local blood circulation; however, use is limited due to local side effects. $^{27}$ Opiates have limited pain relief and adverse effects limit their long term use. ${ }^{28}$ Glucosamine and Chondroitin are widely used in treatment of $\mathrm{OA}$ for symptomatic relief; however, clinical data suggest lack of superiority compared to placebo. ${ }^{29}$ Clinical data suggest no 
therapeutic benefit of Intra-articular hyaluronic acid injections which are used as Viscosupplementation for restoring lubrication, decreasing pain and chondroprotection. ${ }^{30}$ Surgical treatments like total joint replacement are indicated at an advanced stage, where conservative treatments fail to provide adequate pain relief. High cost, expertise and complications limit their wide spread usage. The outcomes of arthroscopic surgical procedures like debridement, lavage is no better than placebo surgery. ${ }^{31}$

The two pathways namely the mechanical and immune pathways discussed earlier play an important role in pathogenesis of OA. The current treatments focus on symptomatic relief, with little or no benefit in halting cartilage destruction and/or disease progression. The very fact that none of the current treatments are able to prevent progression to OA may reflect their inefficiency at controlling the two pathways which are integral to the pathogenesis of OA.

\section{UNDENATURED TYPE II COLLAGEN AND AFLAPIN}

Type II collagen is the structural protein present in articular and hyaline cartilage providing tensile strength, pliability and support to joints. Clinical trials show that UC-II is efficient in the treatment of OA and RA in both humans and animals. ${ }^{32,33} \mathrm{UC}-\mathrm{II}$ is obtained from chicken sternum. UC-II with intact active epitopes interacts with gut associated lymphoid cells in peyers patches. UC-II helps in attenuating body's immune response against destroying joint cartilage by series of immunological reactions called oral tolerance. ${ }^{34} \mathrm{UC}$-II helps in secretion of anti-inflammatory cytokines like IL-10, IL-4 and TGF$\beta$ which suppresses inflammatory degradation of collagen by MMPs to shift balance towards restoring collagen and extracellular matrix synthesis. ${ }^{35}$ This increases functionality, mobility of the joints, alleviates pain in OA patients. $^{36}$

The backbone of articular cartilage is mainly type II collagen, which is lost in early OA. Among collagen derivatives Undenatured collagen with intact epitope helps in oral tolerisation- a process in which the immune response in the inflammatory damage against type II collagen is attenuated. ${ }^{39}$ By repeated oral intake of UC-II, dendritic cells in the gut present the UC-II to lymphoid cells in peyers patches. This gets adsorbed to stimulate $\mathrm{T}$ regulatory cells which in turn suppress $\mathrm{T}$ helper cells stimulation by tolerance. T regulatory cells secrete antiinflammatory cytokines like IL-10, IL-4 and TGF- $\beta$. This suppresses inflammatory degradation of collagen by MMPs to shift balance towards restoring collagen and extracellular matrix synthesis. ${ }^{40}$ The regeneration of cartilage offered by undenatured collagen type-II increases functionality and mobility of the joints and alleviates pain in $\mathrm{OA}$ patients. ${ }^{41}$

Aflapin is a synergistic composition derived from Boswellia serrata. It is selectively enriched with 3-Oacetyl- 11-keto- $\beta$-boswellic acid (AKBA) and specific B Serrata-non-volatile oils to increase bioavailability. Aflapin is a selective and potent 5-lipoxygenase (5-LOX) inhibitor. It decreases leukotriene formation which reduces pro inflammatory mediators like IL- 1 , TNF- $\alpha$, ICAM and MMPs which decrease cartilage destruction and increases glycosaminoglycan's (GAG) formation. ${ }^{37}$ Aflapin as an anti-inflammatory also helps in overall cartilage regeneration. ${ }^{36}$ As a result of its actions, Aflapin can offer good symptomatic control of pain and inflammation and considering its good tolerability may even reduce the dependence on NSAIDs.

\section{RATIONALE FOR THE COMBINATION OF AFLAPIN AND UNDENATURED TYPE-II COLLAGEN}

Undenatured collagen type II acts on immune pathway. It supresses the immune response against type II collagen thus reducing joint inflammation degradation and helping regeneration of the cartilage. Aflapin acts on mechanical pathway by its selective 5-LOX enzyme inhibition. The UC-II and Aflapin combination act on different pathways and offer better control of OA progression along with good symptomatic relief in mild to moderate OA.

\section{CLINICAL EVIDENCE FOR UNDENATURED TYPE II COLLAGEN IN OA}

Lugo et al conducted a double-blinded, placebo-controlled study. In this study, 55 subjects with knee pain, after taking part in standardized step-mill performance test, were randomly allocated to Undenatured type II collagen (UCII) $40 \mathrm{mg} /$ day and placebo groups. The knee discomfort measures subsequent to strenuous step mill exertion were evaluated on baseline i.e. day 0 , and followed on days 7 , day 30 , day 60 , day 90 and day 120 .

Table 1: Clinical studies of Undenatured type II collagen in osteoarthritis.

\begin{tabular}{|c|c|c|c|c|c|}
\hline Year & $\begin{array}{l}\text { Number } \\
\text { of } \\
\text { patients }\end{array}$ & Study design & Study groups & $\begin{array}{l}\text { Parameters } \\
\text { assessed }\end{array}$ & Outcomes \\
\hline $\begin{array}{l}\text { Bakilan et } \\
\text { al }\end{array}$ & 39 & $\begin{array}{l}\text { Single blinded, } \\
\text { randomized, } \\
\text { controlled clinical } \\
\text { study }\end{array}$ & $\begin{array}{l}\text { Acetaminophen grou } \\
\mathrm{p}(1500 \mathrm{mg} / \text { day }) \mathrm{vs} \\
\text { Acetaminophen } \\
\text { (1500 mg/day) + } \\
\text { native type II }\end{array}$ & $\begin{array}{l}\text { VAS } \\
\text { WOMAC } \\
\text { Short Form-36 } \\
\text { (SF-36) }\end{array}$ & $\begin{array}{l}\text { Combination of } \mathrm{AC}+\mathrm{UC}-\mathrm{II} \\
\text { is superior to } \mathrm{AC} \text { in } \\
\text { controlling symptoms at } 90 \\
\text { days. Significant } \\
\text { improvement observed in }\end{array}$ \\
\hline
\end{tabular}




\begin{tabular}{|c|c|c|c|c|c|}
\hline Year & $\begin{array}{l}\text { Number } \\
\text { of } \\
\text { patients }\end{array}$ & Study design & Study groups & $\begin{array}{l}\text { Parameters } \\
\text { assessed }\end{array}$ & Outcomes \\
\hline & & & $\begin{array}{l}\text { collagen group (10 } \\
\mathrm{mg} / \text { day) }\end{array}$ & & $\begin{array}{l}\text { WOMAC total score } \\
(\mathrm{p}=0.004)\end{array}$ \\
\hline Mehra et al & 291 & $\begin{array}{l}\text { Multicentre, non- } \\
\text { interventional, } \\
\text { real life study }\end{array}$ & $\begin{array}{l}\text { UC-II group ( } 40 \\
\text { mg/day) }\end{array}$ & $\begin{array}{l}\text { WOMAC } \\
\text { VAS }\end{array}$ & $\begin{array}{l}\text { UC-II improves pain, } \\
\text { stiffness and enhances } \\
\text { functional mobility at the } \\
\text { end of } 90 \text { days with } \\
\text { significant improvement } \\
\text { observed in WOMAC score } \\
(\mathrm{p}=0.002)\end{array}$ \\
\hline Lugo et al & 191 & $\begin{array}{l}\text { Randomized, } \\
\text { double-blind, } \\
\text { placebo- } \\
\text { controlled clinical } \\
\text { study }\end{array}$ & $\begin{array}{l}\text { UC-II group ( } 40 \\
\text { mg/day), } \\
\text { glucosamine } \\
\text { hydrochloride } \\
\text { (1,500 mg/day) + } \\
\text { chondroitin sulphate } \\
\text { group }(1,200 \\
\text { mg/day), placebo }\end{array}$ & $\begin{array}{l}\text { WOMAC } \\
\text { VAS } \\
\text { LFI }\end{array}$ & $\begin{array}{l}\text { UC-II alleviated knee joint } \\
\text { functions with statistically } \\
\text { significant improvement } \\
\text { observed in WOMAC total } \\
\text { score }(p=0.004)\end{array}$ \\
\hline Lugo et al & 55 & $\begin{array}{l}\text { Randomized, } \\
\text { double-blind, } \\
\text { placebo- } \\
\text { controlled study }\end{array}$ & $\begin{array}{l}\text { UC-II group ( } 40 \\
\text { mg/day), } \\
\text { placebo group }\end{array}$ & $\begin{array}{l}\text { Time to onset } \\
\text { of initial joint } \\
\text { pain. } \\
\text { Time to onset } \\
\text { of maximum } \\
\text { joint pain. } \\
\text { Time to initial } \\
\text { improvement } \\
\text { in knee joint } \\
\text { pain. }\end{array}$ & $\begin{array}{l}\text { UC-II alleviates joint } \\
\text { function in healthy subjects } \\
(\mathrm{p}<0.0001) \text {. }\end{array}$ \\
\hline
\end{tabular}

Table 2: Clinical studies of Aflapin in osteoarthritis.

\begin{tabular}{|c|c|c|c|c|c|}
\hline Year & $\begin{array}{l}\text { Number } \\
\text { of patients }\end{array}$ & Study design & Study groups & $\begin{array}{l}\text { Parameters } \\
\text { assessed }\end{array}$ & Outcomes \\
\hline Vishal et al & $\begin{array}{l}60 \mathrm{OA} \\
\text { subjects }\end{array}$ & $\begin{array}{l}\text { Double blinded, } \\
\text { randomized, placebo } \\
\text { controlled study }\end{array}$ & $\begin{array}{l}\text { Aflapin }(n=30), \\
\text { placebo }(n=30)\end{array}$ & $\begin{array}{l}\text { VAS } \\
\text { WOMAC } \\
\text { LFI }\end{array}$ & $\begin{array}{l}\text { Alleviates pain and } \\
\text { improves joint function at } \\
\text { the end of } 30 \text { days. }\end{array}$ \\
\hline $\begin{array}{l}\text { Sengupta } \\
\text { et al }\end{array}$ & $\begin{array}{l}60 \mathrm{OA} \\
\text { subjects }\end{array}$ & $\begin{array}{l}\text { Double-blind, } \\
\text { randomized, placebo- } \\
\text { controlled study }\end{array}$ & $\begin{array}{l}\text { Aflapin }(n=20), \\
\text { placebo } \\
(n=20), \\
\text { 5-Loxin }(n=20)\end{array}$ & $\begin{array}{l}\text { VAS } \\
\text { WOMAC } \\
\text { LFI }\end{array}$ & $\begin{array}{l}\text { Significant improvements } \\
\text { in pain score and } \\
\text { functional ability were } \\
\text { recorded at } 90 \text { days with } \\
\text { Aflapin group. }\end{array}$ \\
\hline
\end{tabular}

At the end of the study, statistically significant enhanced capacity to extend the knee (measured in degree) was observed in UC-II cohort in comparison to placebo group i.e $\left(81.0 \pm 1.3^{\circ}\right.$ versus $74.0 \pm 2.2^{\circ}, \mathrm{p}=0.011$ at day 120$)$ and baseline $\left(81.0 \pm 1.3^{\circ}\right.$ versus $\left.73.2 \pm 1.9^{\circ}, \mathrm{p}=0.002\right)$. Also, the knee discomfort measures of the study reveals that UC-II alleviates joint function in healthy subjects $(\mathrm{p}<0.0001)$ in contrast to placebo group. ${ }^{38}$

Lugo et al summarized results from a double-blinded, placebo-controlled clinical study where 191 OA subjects were randomized into UC-II group $40 \mathrm{mg} /$ day, glucosamine hydrochloride plus chondroitin sulfate (GC) group $1500 \mathrm{mg} \mathrm{G}+1200 \mathrm{mg} \mathrm{C}$, and the placebo group. The subjects were followed on day 0 (baseline), 7, 30, 60, $90,120,150$ and day 180 to assess efficacy and tolerability of UC-II in knee osteoarthritis. The difference in total WOMAC score between UC-II, GC and placebo groups from baseline to 180 days was measured as primary endpoint. The difference in mean VAS; mean WOMAC subscales; LFI; and knee flexion were measured as secondary endpoints.

Statistically significant reduction was observed in total WOMAC score $(\mathrm{p}=0.002)$, VAS score $(\mathrm{p}=0.002)$ and LFI score $(\mathrm{p}=0.009)$ in the UC-II in contrast to the placebo 
group at day 180 compared to baseline day 0 . The same is true between UC-II and GC group. UC-II alleviated knee joint functions in knee osteoarthritis patients. ${ }^{39}$

In a single blinded, controlled clinical study by Bakilan et al., in which 39 patients were randomly assigned to acetaminophen group (AC) $1500 \mathrm{mg} /$ day $(\mathrm{n}=19)$ and to AC $1500 \mathrm{mg} /$ day + UC-II group $10 \mathrm{mg} /$ day $(\mathrm{n}=20)$. The efficacy was assessed using VAS, WOMAC, and Short Form-36 (SF-36) scores for 3 months. Statistically significant improvement was observed at day 90 in parameters like VAS walking $(\mathrm{p}<0.001)$, WOMAC total $(\mathrm{p}=0.004)$ and SF36 physical functioning $(\mathrm{p}=0.039)$. When $\mathrm{AC}+\mathrm{UC}-\mathrm{II}$ and $\mathrm{AC}$ groups were compared, significant change was observed. $50 \%$ change in VAS walking score was observed in AC+UC-II $(p=0.002)$. Thus, the combination of $\mathrm{AC}+\mathrm{UC}-\mathrm{II}$ was superior to $\mathrm{AC}$ in controlling symptoms in OA patients. ${ }^{40}$

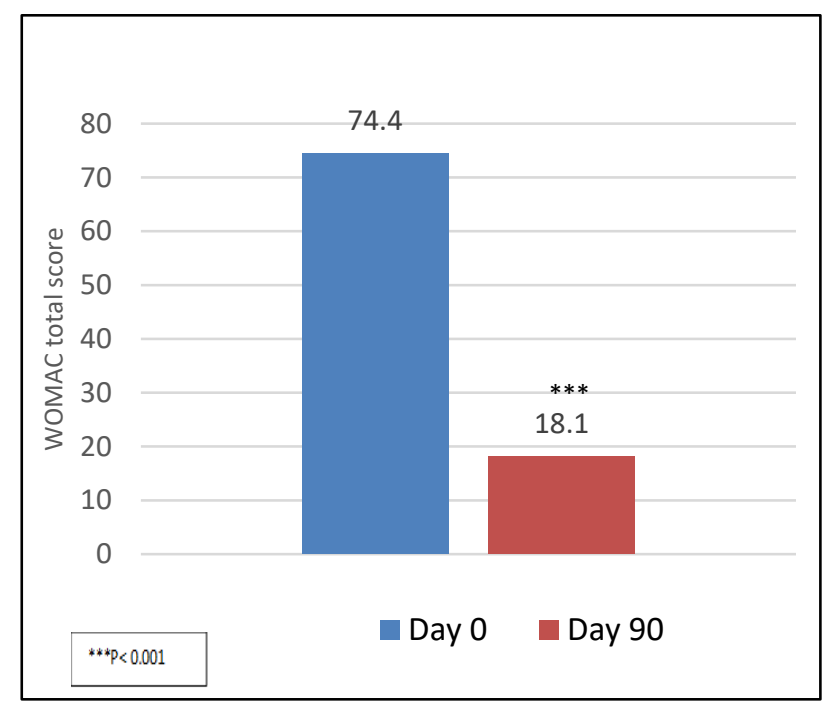

Figure 2: Reduction in WOMAC total score with FDC of Aflapin and Undenatured type ii collagen.

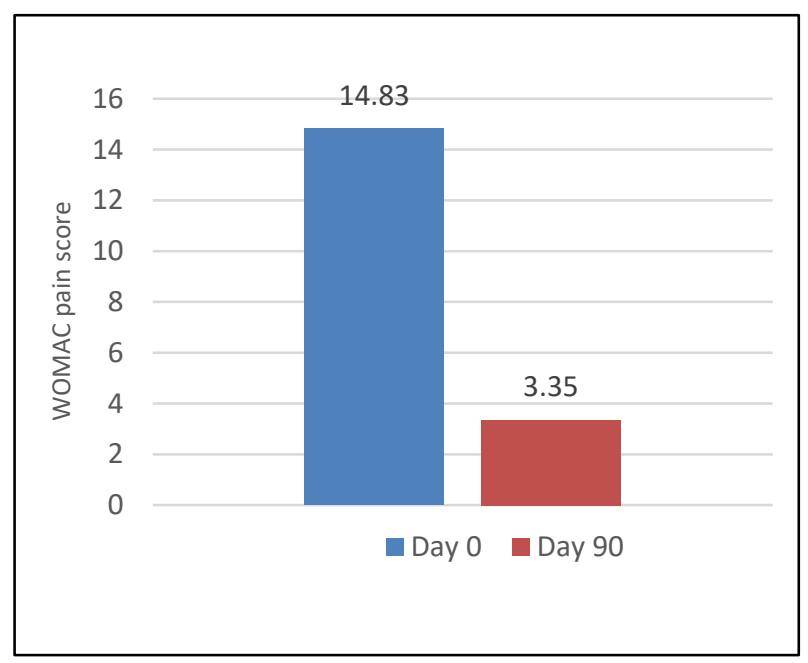

Figure 3: Reduction in WOMAC pain score with FDC of Aflapin and Undenatured type II collagen.

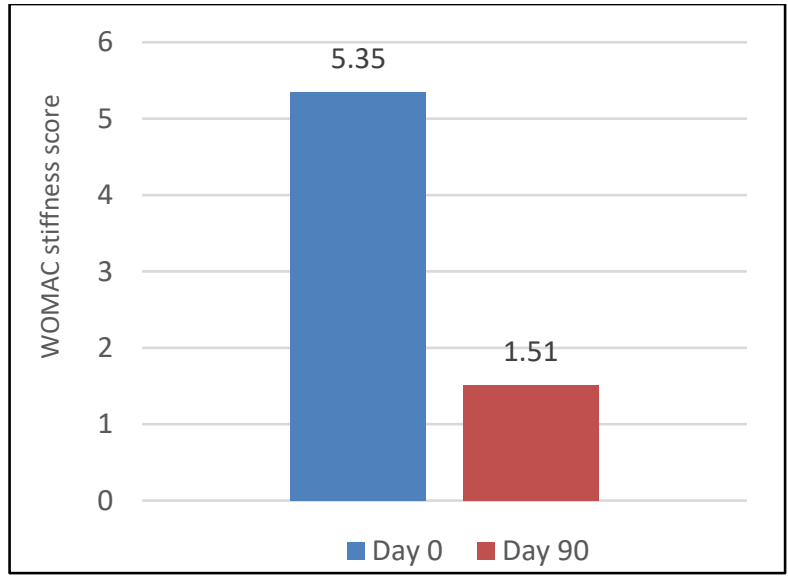

Figure 4: Reduction in WOMAC stiffness score with FDC of Aflapin and Undenatured type II collagen.

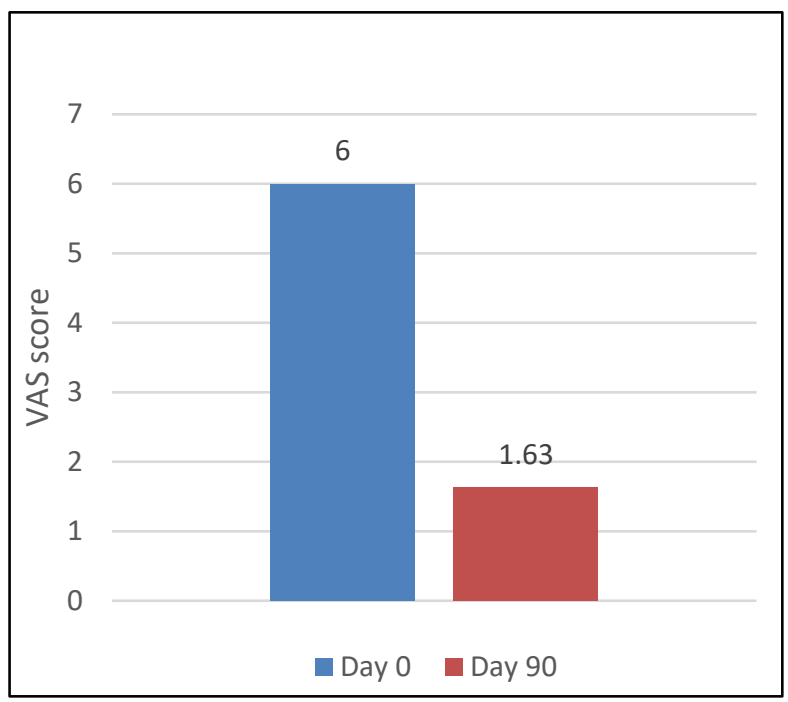

Figure 5: Reduction in VAS score with FDC of Aflapin and Undenatured type II collagen.

In a multicentre, non-interventional, real life study by Mehra et al, 291 patients with knee OA were treated with UC-II (40 mg/day). Efficacy was assessed by differences in VAS and WOMAC scores from baseline to end of the study. Safety was assessed by any undesirable effects or severe adverse events occurrence during the study. The patients were assessed for safety and efficacy at baseline day 0, day 30, day 60 and day 90 of the treatment. Statistically significant improvement was noticed at day 90. The WOMAC score recorded mean change of 20.7 $\pm 12.6,(p<0.0001)$ and the VAS score shows mean change of $-3.3 \pm 1.8, \quad(p<0.0001)$. UC-II helps in ameliorating pain, stiffness and enhances functional mobility in patients with knee OA. ${ }^{41}$

\section{CLINICAL EVIDENCE OF AFLAPIN IN OSTEOARTHRITIS}

In one double blinded, randomized, placebo controlled clinical study of Aflapin, 60 patients with unilateral or 
bilateral OA of the knee were recruited. The patients were assigned Aflapin $100 \mathrm{mg} /$ day or placebo arm for 1 month. The patients were assessed for change in pain, stiffness and physical function using Western Ontario and McMaster Universities Osteoarthritis Index (WOMAC), Lequesne's functional index (LFI) and visual analog scale (VAS) scores on day 5,15 , and 30 respectively. Safety was also evaluated with changes in biochemical and haematological parameters at all visits. As compared to baseline, significant reductions $(\mathrm{p}<0.001)$ in VAS, LFI, WOMAC pain, WOMAC stiffness and WOMAC function scores were observed after 30 days of supplementation with Aflapin. VAS, LFI, WOMAC pain, WOMAC stiffness and WOMAC function scores decreased by $49.1 \%, 34.4 \%$, $49.5 \%, 48.4 \%$ and $45.2 \%$, respectively as compared to baseline. Compared to placebo, VAS score decreased by $14.8 \%$ and LFI scores decreased by $16.3 \%$ on day 5 of treatment. The reductions in WOMAC scores were not significant after 5 days of treatment. In laboratory and haematological parameters, no significant changes were observed after 30 days of treatment with Aflapin. This study demonstrated that Aflapin significantly alleviates pain and improves joint function beginning at day 5 of treatment. $^{42}$

In another double blinded, placebo controlled study, 60 patients suffering with moderate to mild osteoarthritis were recruited and randomized to Aflapin group $100 \mathrm{mg} /$ day $(\mathrm{n}=20), 5$-Loxin group $100 \mathrm{mg} /$ day $(\mathrm{n}=20)$, and placebo $(n=20)$. The patients were evaluated for pain, physical function and stiffness using WOMAC index, LFI score, VAS scale on day 0 baseline, day 7, day 30, day 60 , day 90 respectively. Safety was evaluated by assessment of clinical and laboratory parameters at every visit. By day 7, VAS, LFI, WOMAC pain, WOMAC stiffness and WOMAC function scores significantly reduced by $12.8 \%$ $(\mathrm{p}=0.0004), 9.17 \%(\mathrm{p}=0.003), 11.78 \%(\mathrm{p}=0.012), 18.48 \%$ $(\mathrm{p}=0.012)$ and $10.24 \% \quad(\mathrm{p}=0.005)$ respectively in the Aflapin treated group compared to baseline. After 90 days of treatment statistically significant alleviation in pain scores, physical ability score were observed in the Aflapin group as compared to baseline. The VAS, LFI, WOMAC pain, WOMAC stiffness and WOMAC functional ability scores were reduced by $47.3 \% \quad(p<0.0001), 35.8 \%$ $(\mathrm{p}=0.0004), 61.7 \% \quad(\mathrm{p}<0.0001), 60.1 \% \quad(\mathrm{p}=0.0001)$ and $49.4 \%(\mathrm{p}=0.0001)$ respectively at the end of treatment period (Day 90) in the Aflapin group as compared to baseline. Similarly the Loxin group showed a reduction by $12.8 \%(\mathrm{p}=0.0004), 9.17 \% \quad(\mathrm{p}=0.003), 11.78 \% \quad(\mathrm{p}=0.012)$, $18.48 \%(\mathrm{p}=0.012)$ and $10.24 \%(\mathrm{p}=0.005)$ in the VAS, LFI, WOMAC pain, WOMAC stiffness and WOMAC functional ability scores respectively compared to baseline. No significant variations were observed in haematological and biochemical parameters compared to baseline in the intervention groups. This study established superior efficacy of Aflapin over 5-Loxin in reducing pain by day 7 , and also safety of Aflapin for therapeutic use. ${ }^{23}$

\section{CLINICAL EVIDENCE OF THE FIXED DOSE COMBINATION OF UNDENATURED TYPE-II COLLAGEN AND AFLAPIN IN OA}

In a pilot, observational, multicentric study in India 40 patients suffering with unilateral and bilateral osteoarthritis were treated with fixed dose combination of native (Undenatured) Type -II Collagen (UC-II) $40 \mathrm{mg}+$ Aflapin $100 \mathrm{mg}$ capsules once a day for 3 months. Efficacy was assessed by change in VAS and WOMAC scores from baseline and safety was evaluated by change in biochemical and laboratory parameters. The patients were assessed at baseline day 0 and then followed up on day 5 , day 15 , day 30 , day 60 , and day 90 respectively. VAS score decreased by $72.8 \%$ and WOMAC total score decreased by $75.6 \%$ after 90 days of treatment with a fixed dose combination of native (Undenatured) Type II Collagen and Aflapin. At day 5, significant reduction in VAS score and total WOMAC score was observed. Alleviation in joint pain and improvement in physical function was observed as early as day 5 with the combination.

This study concludes that the fixed dose combination of native (Undenatured) Type II Collagen and Aflapin was efficient in reducing pain, inflammation and joint stiffness with excellent tolerability. ${ }^{24}$

\section{CONCLUSION}

Both immmunlogical and mechanical pathways play an important in the pathogenesis of OA. Therefore, a multimodal therapeutic approach with agents which can target both the pathways seems rational. The combination of Undenatured type II Collagen and Aflapin seems to be a rational approach to meet the need-gap in OA treatment as well as providing early symptomatic relief in OA along with preventing progression of OA. It seems a reasonable choice for mild to moderate OA. More studies with this combination will add further value to this therapeutic approach.

\section{Funding: No funding sources Conflict of interest: None declared Ethical approval: Not required}

\section{REFERENCES}

1. Chen D, Shen J, Zhao W. Osteoarthritis: toward a comprehensive understanding of pathological mechanism: Bone Research. 2017;5:16044.

2. Hunter D, Zeinstra SB, Osteoarthritis. Lancet. 2019;393:1745-59.

3. Lozada C. Progression of Osteoarthritis, Medscape. 2020.

4. Doherty M. Clinical manifestations and diagnosis of osteoarthritis. 2020.

5. Yuan. Immunologic Intervention in the Pathogenesis of Osteoarthritis. Arthritis and Rheumatism. 2003;48(3):602-11. 
6. Attur M. Bulletin of the NYU Hospital for Joint Diseases. 2012;70(2):99-108.

7. Martel-Pelletier J, Wildi LM, Pelletier JP. Future therapeutics for osteoarthritis. Bone. 2012;51(2):297-311.

8. Westacott CI, Sharif M. Cytokines in osteoarthritis: mediators or markers of joint destruction? Semin Arthritis Rheum. 1996;25:254-72.

9. Moos V, Fickert S, Muller B, Weber U, Sieper J. Immunohistological analysis of cytokine expression in human osteoarthritic and healthy cartilage. J Rheumatol. 1999; 26:870-9.

10. Crowley D. Safety and efficacy of undenatured type II collagen in the treatment of osteoarthritis of the knee: a clinical trial. Int J Med Sci. 2009;6(6):31221.

11. Tetlow LC, Adlam DJ, Woolley DE. Matrix metalloproteinase and proinflammatory cytokine production by chondrocytes of human osteoarthritic cartilage: associations with degenerative changes. Arthritis Rheum. 2000;44:585-94.

12. Godessart N, Kunkel SL. Chemokines in autoimmune disease. Curr Opin Immunol 2001; 13:670-5.

13. Koch AE, Kunkel SL, Shah MR, Fu R, Mazarakis DD, Haines GK, et al. Macrophage inflammatory protein-1: a C-C chemokine in osteoarthritis. Clin Immunol Immunopathol. 1995;77:307-14.

14. Yuan GH, Masuko-Hongo K, Sakata M, Tsuruha J, Onuma H, Nakamura $\mathrm{H}$, et al. The role of C-C chemokines and their receptors in osteoarthritis. Arthritis Rheum. 2001;44:1056-70.

15. Glant T, Mikecz K. Antigenic profiles of human, bovine and canine articular chondrocytes. Cell Tissue Res. 1986;244:359-69.

16. Homandberg GA. Potential regulation of cartilage metabolism in osteoarthritis by fibronectin fragments. Front Biosci. 1999;4:D713-30.

17. Sokolove J, Lepus CM. Role of inflammation in the pathogenesis of osteoarthritis: latest findings and interpretations. Ther Adv Musculoskeletal Dis. 2013;5(2):77-94.

18. Ishii H, Yoshino S, Nakamura H, Tsuruha J, Kato T, Nishioka K. Immunophenotyping of synovial activated $\mathrm{T}$ cells and expression of Th1/Th2 cytokines in osteoarthritis [abstract]. Arthritis Rheum 1999;42(9):S254.

19. Kandahari A, Yang X, Dighe A, Pan D, Recognition of Immune Response for the Early Diagnosis and Treatment of Osteoarthritis, J. Immunol Res. 2015;113.

20. Sakata M, Tsuruha JI, Masuko-Hongo K, Nakamura H, Matsui T, Sudo A, et al. Autoantibodies to osteopontin in patients with osteoarthritis and rheumatoid arthritis. J Rheumatol. 2001;28:1492-5.

21. Jasin HE. Autoantibody specificities of immune complexes sequestered in articular cartilage of patients with rheumatoid arthritis and osteoarthritis. Arthritis Rheum. 1985;28:241-8.
22. Vishal AA, Mishra A, Raychaudhuri SP. A double blind, randomized, placebo controlled clinical study evaluates the early efficacy of aflapin in subjects with osteoarthritis of knee. Int J Med Sci. 2011;8(7):61522.

23. Sengupta K, Krishnaraju AV, Vishal AA. Comparative efficacy and tolerability of 5-Loxin and Aflapin Against osteoarthritis of the knee: a double blind, randomized, placebo controlled clinical study. Int J Med Sci. 2010;7(6):366-77.

24. Jain AV, Jain KA, N. Vijayaraghavan. AflaB2® and osteoarthritis: a multicentric, observational, postmarketing surveillance study in Indian patients suffering from knee osteoarthritis. Int J Res Orthop. 2021;7(1):1-115.

25. Lugo JP, Saiyed ZM, Lau FC. Undenatured type II collagen (UC-II ${ })$ for joint support: a randomized, double-blind, placebo-controlled study in healthy volunteers. J Int Soc Sports Nutr. 2013;10(1):48.

26. Lugo JP, Saiyed ZM, Lane NE. Efficacy and tolerability of an undenatured type II collagen supplement in modulating knee osteoarthritis symptoms: a multicenter randomized, double-blind, placebo-controlled study. Nutr J. 2016;15:14.

27. Bakilan F, Armagan O, Ozgen M. Effects of Native Type II Collagen Treatment on Knee Osteoarthritis: A Randomized Controlled Trial. Eurasian J Med. 2016;48(2):95-101.

28. Mehra A, Anand P, Borate M. A non-interventional, prospective, multicentric real life Indian study to assess safety and effectiveness of undenatured type 2 collagen in management of osteoarthritis. Int J Res Orthop. 2019;5(2):315-32.

29. Kolasinski SL, Neogi T, Hochberg MC. 2019 American College of Rheumatology/Arthritis Foundation Guideline for the Management of Osteoarthritis of the Hand, Hip, and Knee. Arthritis Care Res (Hoboken). 2020;72(2):149-62.

30. Bannuru RR, Dasi UR, McAlindon TE. Reassessing the role of acetaminophen in osteoarthritis: Systematic review and meta-analysis. Osteoarthritis Cartilage. 2010;18:S250.

31. Berenbaum F. Osteoarthritis as an inflammatory disease (osteoarthritis is not osteoarthrosis!). Osteoarthr Cartil. 2013;21(1):16-21.

32. Laev SS, Salakhutdinov NF. Anti-arthritic agents: progress and potential. Bioorg Med Chem. 2015;23(13):3059-80.

33. Chou R, McDonagh MS, Nakamoto E, Griffin J. Analgesics for Osteoarthritis: An Update of the 2006 Comparative Effectiveness Review [Internet] Rockville (MD): Agency for Healthcare Research and Quality (US). 2011.

34. Kon E, Filardo G, Drobnic M. Non-surgical management of early knee osteoarthritis. Knee Surg Sports Traumatol Arthrosc. 2012;20(3):436-49.

35. Bruton LL, Lazo J, Parker KL. Goodman \& Gilmans. The Pharmacological Basis of Therapeutics. 11th edition. 2005: 438-440. 
36. Roman-Blas JA. CS/GS Combined Therapy Study Group. Combined Treatment With Chondroitin Sulfate and Glucosamine Sulfate Shows No Superiority Over Placebo for Reduction of Joint Pain and Functional Impairment in Patients With Knee Osteoarthritis: A Six-Month Multicenter, Randomized, Double-Blind, Placebo-Controlled Clinical Trial [published correction appears in Arthritis Rheumatol. Arthritis Rheumatol. 2017;69(1):77-85.

37. Rutjes AW, Jüni P, da Costa BR, Trelle S, Nüesch E, Reichenbach S. Viscosupplementation for osteoarthritis of the knee: a systematic review and meta-analysis. Ann Intern Med. 2012;157:180-91.

38. Moseley JB, O’Malley K, Petersen NJ, Menke TJ, Brody BA, Kuykendall DH, et al. A controlled trial of arthroscopic surgery for osteoarthritis of the knee. N Engl J Med. 2002;347:81-8.

39. Bakilan F, Armagan O, Ozgen M, Tascioglu F, Bolluk O, Alatas O. Effects of Native Type II Collagen Treatment on Knee Osteoarthritis: A
Randomized Controlled Trial. Eurasian J Med. 2016;48:95-101.

40. Crowley D. Safety and efficacy of undenatured type II collagen in the treatment of osteoarthritis of the knee: a clinical trial. Int J Med Sci. 2009;6(6):31221.

41. Mahajan M, Rathod NR, Narayanan V. Multimodal Anti-Inflammatory Approach to Osteoarthritis Management - Review of T Cell Immunomodulation with Undenatured (Native) Collagen Type II and LOX Inhibition with Boswellia. Nov Tech Arthritis Bone Res. 2019;3(4):555618.

42. Suva, A flapin: A novel and selective 5-Iipoxygenase inhibitor for arthritis management. Ind. J. Pain. 2018;32 (1):16-23.

Cite this article as: Jain K, Mehra AA, Mehta KD, Dsouza L, Kumar R. Role of Undenatured collagen type II and Aflapin combination in the management of osteoarthritis: a review. Int J Res Orthop 2021;7:885-93. 